\title{
ANALISIS KAPASITAS JARINGAN DRAINASE DI PASAR KEMIS CIKUPA KABUPATEN TANGERANG
}

\author{
Daniel David Camberra Simanungkalit ${ }^{1}$, Arianti Sutandi ${ }^{2}$, dan Vittorio Kurniawan ${ }^{3}$
}

\author{
${ }^{1}$ Program Studi Sarjana Teknik Sipil, Universitas Tarumanagara, Jl. Letjen S. Parman No.1 Jakarta \\ Email: daniel.325150026@stu.untar.ac.id \\ ${ }^{2}$ Program Studi Sarjana Teknik Sipil, Universitas Tarumanagara, J1. Letjen S. Parman No.1 Jakarta \\ Email: ariantis@ft.untar.ac.id
}
${ }^{3}$ Program Studi Sarjana Teknik Sipil, Universitas Tarumanagara, Jl. Letjen S. Parman No.1 Jakarta
Email:vkurniawan@ft.untar.ac.id

\begin{abstract}
Urban drainage is drainage in part or entire areas (cities), which is to manage/control surface water, so that it doesn't disturb and/or harm people. This study aims to determine the size of the existing drainage channel whether it is able to accommodate the maximum discharge from the analysis of rainfall frequency in Pasar Kemis-Cikupa area. For this reason, there are several things that need to be analyzed. First is the rainfall plan, then selection of the rainfall distribution that will be used for testing using the Chi-Square Test and Kolmogorov-Smirnov Test and the data used is the rainfall data for the past 15 years, then after testing the results obtained, the method of calculating the rainfall, can be analyzed with the Log Pearson Type-3 which obtained results is 134,36 $\mathrm{mm}$ with a return period of 5 years, after that the analysis continues to calculate the intensity of rainfall in this study using the mononobe method, for the next analysis is the calculation of the discharge plan 5-year return period in this study using the rational method. After all the analyzes were carried out, it was concluded that the existing drainage wasn't able to accommodate the discharge from the hydrological plan.
\end{abstract}

Keywords: drainage; rainfall intensity; discharge.

\begin{abstract}
ABSTRAK
Drainase perkotaan adalah drainase di bagian atau seluruh wilayah (kota), yang berfungsi mengelola/mengendalikan air permukaan, sehingga tidak mengganggu dan/atau merugikan masyarakat. Penelitian ini memiliki tujuan untuk mengetahui ukuran dari saluran drainase eksisting apakah sudah mampu menampung debit maksimum dari hasil analisis frekuensi curah hujan di daerah Pasar Kemis-Cikupa. Untuk itu ada beberapa hal yang perlu dianalisis pertama adalah curah hujan rencana, dalam pemilihan metode distribusi curah hujan rencana yang akan digunakan untuk diuji, dengan menggunakan Uji Chi-Square dan Uji Kolmogorov-Smirnov dan data yang digunakan adalah data hujan selama 15 tahun terakhir, lalu setelah diuji didapat hasil bahwa metode perhitungan curah hujan rencana untuk data dalam penelitian ini dapat dianalisis dengan metode distribusi Log Pearson Tipe-3 yang didapat hasil sebesar 134,36 mm dengan periode ulang 5 tahun, setelah itu analisis dilanjutkan untuk perhitungan intensitas hujan yang dalam penelitian ini dengan menggunakan metode mononobe untuk analisis selanjutnya adalah perhitungan debit rencana periode ulang 5 tahun yang dalam penelitian ini menggunakan metode rasional. Setelah semua analisis tadi dilakukan didapat hasil yang menyimpulkan bahwa drainase eksisting tidak mampu lagi untuk menampung debit dari hasil hidrologi rencana.
\end{abstract}

Kata kunci: drainase; intensitas hujan; debit.

\section{PENDAHULUAN}

Jalan otonom Pasar Kemis-Cikupa di Kabupaten Tangerang merupakan jalan yang vital bagi masyarakat yang tinggal di Kecamatan Cikupa dan sekitarnya. Jalan ini merupakan akses utama bagi masyarakat baik yang menuju ke Tol Cikupa maupun yang keluar dari ke Tol Cikupa. Namun objek yang vital ini sering sekali terkena genangan air sehingga banyak sekali masyarakat yang hilir-mudik dari dan menuju ke tol Cikupa aktivitasnya terganggu. Berdasarkan data demografi dari (Buku Putih Sanitasi Kabupaten Tangerang) penduduk di Kecamatan Cikupa pada 
tahun 2012 sebanyak 252.289 penduduk dan mereka sering terkena dampak dari adanya genangan air di objek vital tersebut. Oleh karena itu perlu dicari penyebab genangan air di daerah tersebut. Menurut (Supriadi) genangan bisa saja timbul apabila saluran drainase mengalami masalah dan kendala. Sehingga menyebabkan air hujan tidak dapat disalurkan secara sempurna melalui parit-parit yang ada. Penyebab dari gangguan sistem drainase ini sendiri, kembali disebabkan oleh penumpukan sampah yang berlebih. Maka dari itu hal-hal tersebut jangan terjadi lagi maka perlu dilakukan penelitian ini untuk mencari penyebab genangan air tersebut yang terjadi di sepanjang jalan otonom Pasar Kemis-Cikupa. Genangan air bisa bisa saja timbul apabila saluran drainase mengalami masalah dan kendala, oleh sebab itu harus diteliti apa saja masalah yang menjadi kendala dari saluran drainase di Pasar Kemis-Cikupa.

Rumusan masalah untuk penelitian ini adalah sebagai berikut:

1. Bagaimana genangan air bisa terjadi di drainase yang ada di daerah Pasar Kemis-Cikupa?

2. Analisis frekuensi curah hujan apa saja yang dapat digunakan, apakah dengan metode distribusi normal, log normal, log pearson tipe 3, dan/atau metode gumbel tipe 1 ?

3. Pada periode ulang berapa yang dapat memenuhi kapasitas saluran eksisting? Apakah sesuai untuk periode ulang 2, 5, 10, 25, 50, 100 tahun?

4. Bagaimana analisis intensitas curah hujan?

5. Bagaimana analisis debit rancangan dengan debit eksisting?

6. Apakah debit puncak mempengaruhi ukuran dari saluran awal?

Maksud dari penelitian yang akan dilakukan ini yaitu untuk mengetahui ukuran dari saluran drainase eksisting apakah sudah mampu menampung debit maksimum dari hasil analisis frekuensi curah hujan di daerah tersebut.

Tujuan dari penelitian ini adalah:

1. Mengetahui penyebab genangan air di drainase pada daerah Pasar Kemis-Cikupa.

2. Mengetahui apa saja yang perlu diperbaiki dari drainase eksisting tersebut.

\section{Daerah Tangkapan Air}

Daerah Tangkapan Air (DTA) adalah suatu kawasan yang berfungsi sebagai daerah penadah air yang mempunyai manfaat penting untuk memepertahankan kelestarian fungsi sumber air di wilayah daerah (Puji, 2017). Berikut ini perbedaan DAS dengan DTA. Asdak (2002) menyatakan pengertian DAS sebagai suatu wilayah daratan yang secara topografik dibatasi oleh punggung-punggung gunung yang menampung dan menyimpan air hujan untuk kemudian menyalurkannya ke laut melalui sungai utama. Sedangkan wilayah daratan tersebut dinamakan Daerah Tangkapan Air (DTA) atau Water Catchment Area yang merupakan suatu ekosistem dengan unsur utamanya terdiri atas sumberdaya alam (tanah, air, dan vegetasi) dan sumberdaya manusia sebagai pemanfaat sumber daya alam. Untuk sistem drainase perkotaan yang digunakan adalah DTA.

\section{Hidrologi}

Hujan berasal dari awan hujan yang berkondensasi dan jatuh ke permukaan tanah dipengaruhi fenomena alam sehingga kejadiannya begitu acak baik waktu, lokasi, dan besarannya, akibatnya nilai yang sesungguhnya sulit diperkirakan. Begitu pun untuk membuktikan satu seri pencatatan dari data hujan adalah sangat sulit, sehingga terkadang untuk meramal atau menambah data pencatatan hujan, pembuatan simulasi data hujan sintetik diperlukan. Berbagai metode sudah dikembangkan oleh para peneliti dalam bidang teknik dan sain untuk membuktikan informasi ini. Metode yang paling banyak dipergunakan sekarang adalah metode deterministik dan metode stokastik. Hidrologi berasal dari Bahasa Yunani yaitu terdiri dari kata hydros yang berarti air dan kata logos yang berarti ilmu, dengan demikian secara umum hidrologi adalah ilmu yang mempelajari tentang air. Secara lebih mendetail, hidrologi adalah cabang ilmu teknik sipil yang mempelajari pergerakan, distribusi dan kualitas air di seluruh bumi, termasuk siklus hidrologi dan sumber daya air. Siklus hidrologi adalah suatu rangkaian proses yang terjadi dengan air yang terdiri dari penguapan, presipitasi, infiltrasi dan pengaliran keluar (out flow). Penguapan terdiri dari evaporasi dan transpirasi. Uap yang dihasilkan mengalami kondensasi dan dipadatkan membentuk awan yang nantinya kembali menjadi air dan turun sebagai presipitasi. Sebelum tiba di permukaan bumi presipitasi tersebut sebagian langsung menguap ke udara, sebagian tertahan oleh tumbuh-tumbuhan (intersepsi) dan sebagian mencapai permukaan tanah.

\section{Drainase perkotaan}

Drainase perkotaan adalah drainase di bagian atau seluruh wilayah (kota), yang berfungsi mengelola/mengendalikan air permukaan, sehingga tidak mengganggu dan/atau merugikan masyarakat (Kementerian Pekerjaan Umum Direktorat Jenderal Cipta Karya). 


\section{Fungsi drainase}

Drainase memiliki banyak fungsi, diantaranya (Moduto, 2011):

1. Mengeringkan daerah becek dan genangan air.

2. Mengendalikan akumulasi limpasan air hujan yang berlebihan.

3. Mengendalikan erosi, kerusakan jalan, dan kerusakan infrastruktur.

4. Mengelola kualitas air.

\section{Pemilihan fungsi distribusi}

Data debit banjir sesaat hasil pengamatan > 20 tahun dibuat histogramnya yang membentuk suatu kurva dan coba untuk didekati dengan salah satu fungsi distribusi seperti:distribusi Normal, Log Normal, Gama, Pearson, Log Pearson, Gumbel dan lain-lain. Fungsi distribusi yang paling dekat dengan data observasi digunakan untuk menghitung besarnya banjir/ hujan rencana. (SNI 2415:2016). Pengujian terhadap hubungan antara fungsi distribusi data obserasi dan fungsi distribusi terpilih dapat menggunakan tes Chi-Square atau Kolmogorov - Smirnov. (SNI 2415:2016).

\section{Pengujian kecocokan fungsi distribusi (Goodness of Fit)}

Kecocokan dalam pemilihan fungsi distribusi diuji dengan uji kecocokan menggunakan metode pengujian dan dengan confidence interval (tingkat interval kepercayaan) tertentu dapat menggunakan Metode Chi-Square dan Metode Kolmogorov-Smirnov. Jenis sebaran peluang/fungsi distribusi yang sering digunakan pada analisis frekuensi untuk hujan ekstrim di Indonesia adalah Pearson III, Log Pearson III, Gumbel Tipe 1, Normal, Log Normal 2, dan Log Normal 3 parameter. (SNI 2415:2016).

\section{Uji Chi-Square diketik ulang dari (SNI 2415:2016)}

Metode ini menganggap pengamatan membentuk variabel acak dan dilakukan secara statistik dengan mengikuti kurva distribusi chi square dengan derajat kebebasan k-p-1, dengan p merupakan jumlah parameter yang diesitimasi dari data. Uji statistik ini berdasarkan pada bobot jumlah kuadrat perbedaan antara pengamatan dan teoritisnya yang dibagi dalam kelompok kelas. Uji kecocokan ini dapat dilihat pada persamaan (1):

$$
\mathrm{X}^{\frac{\mathrm{k}}{(\mathrm{i}=1)}}=\frac{(\mathrm{Oi}-\mathrm{Ei})^{2}}{\mathrm{Ei}}
$$

Keterangan:

$\begin{array}{lll}X^{\frac{k}{(i=1)}} & = & \text { adalah parameter chi-square terhitung } \\ \mathrm{k} & = & \text { adalah jumlah sub kelompok } \\ \mathrm{Oi} & = & \text { adalah jumlah nilai pengamatan pada sub kelompok ke } \mathrm{i} \\ \mathrm{Ei} & = & \text { adalah jumlah nilai teoritis pada sub kelompok ke } \mathrm{i}\end{array}$

Jika hasilnya $X \frac{k}{n}$ besar menunjukkan bahwa distribusi yang dipilih tidak cocok, tetapi uji ini dapat memberikan hasil yang baik jika mempunyai data yang panjang. Kottegoda (1996) menyarankan sebaiknya $\mathrm{n} \leq 50$ tahun dan jumlah kelas interval $\leq 5$.

Urutan pemeriksaan kesesuaian distribusi adalah sebagai berikut :

a. Urutkan data pengamatan dari data kecil ke besar atau sebaliknya.

b. Kelompokkan data pengamatan menjadi beberapa " $k$ " kelas interval $(\mathrm{k}$ diambil $=5)$.

c. Catat frekuensi data pengamatan pada setiap kelas interval.

d. Hitung frekuensi kejadian yang diharapkan "F".

e. Hitung nilai; vi. Tetapkan nilai derajat kebebasan.

f. Tetapkan besar tingkat kepercayaan (confidence level, misal 95\%).

g. Cari kritis dari tabel harga kritis Chi-Square.

Bandingkan $X^{2}$ hitungan dengan $X^{2}$ kritis, Bila hitungan $X^{2}<X^{2}$ kritis, berarti metode distribusi yang diperiksa dapat diterima. 
2. Uji Kolmogorov - Smirnov diketik ulang dari (SNI 2415:2016)

Untuk menghindarkan hilangnya informasi data pada uji Chi-Square akibat pengelompokan data dalam kelas-kelas interval, ada beberapa metode lain yang telah dikembangkan. Salah satu metode yang sering digunakan adalah uji Kolmogorov-Smirnov (1993). Uji kecocokan ini adalah uji kecocokan "non parametric" karena tidak mengikuti distribusi tertentu. Uji ini menghitung besarnya jarak maksimum secara vertikal antara pengamatan dan teotitisnya dari distribusi sampelnya. Perbedaan jarak maksimum untuk Kolmogorov - Smirnov tertera pada Persamaan (2).

$$
\operatorname{Dn}=\max |\mathrm{P}(\mathrm{x})-\mathrm{Po}(\mathrm{x})|
$$

Keterangan:

Dn $\quad=$ adalah jarak vertikal $/$ maksimum antara pengamatan dan teoritisnya.

$\mathrm{P}(\mathrm{x}) \quad=$ adalah probabilitas dari sampel data.

$\mathrm{Po}(\mathrm{x}) \quad=$ adalah probabilitas dari teoritisnya.

Distribusi dikatakan cocok jika nilai $\mathrm{Dn}<\mathrm{D}$ kritisnya pada derajat kepercayaan yang diinginkan.Urutan uji ini adalah sebagai berikut :

a. Susun data curah hujan harian rerata tiap tahun dari kecil ke besar atau sebaliknya;

b. Hitung probabilitas untuk masing-masing data hujan dengan persamaan Weibull sebagai berikut:

$$
\mathrm{P}=\frac{\mathrm{m}}{\mathrm{n}+1} \times 100 \%
$$

Keterangan:

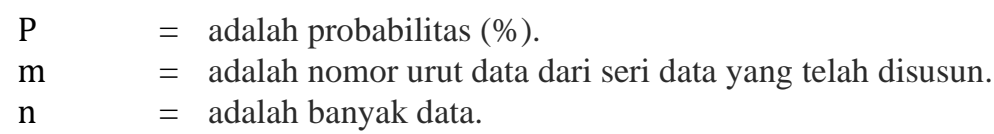

Berikut ini adalah nilai harga kritis dari uji Kolmogorov Smirnov yang terdapat pada tabel 1 berikut ini.

Tabel 1. Harga kritis Kolmogorov Smirnov

\begin{tabular}{ccccc}
\hline \multirow{4}{n}{$\mathbf{n}$} & \multicolumn{4}{c}{$\boldsymbol{\alpha}$} \\
\cline { 2 - 5 } $\mathbf{5}$ & $\mathbf{0 , 2}$ & $\mathbf{0 , 1}$ & $\mathbf{0 , 0 5}$ & $\mathbf{0 , 0 1}$ \\
\hline $\mathbf{1 0}$ & 0,45 & 0,51 & 0,56 & 0,67 \\
\hline $\mathbf{1 5}$ & 0,27 & 0,37 & 0,41 & 0,49 \\
\hline $\mathbf{2 0}$ & 0,23 & 0,26 & 0,29 & 0,36 \\
\hline $\mathbf{2 5}$ & 0,21 & 0,24 & 0,27 & 0,32 \\
\hline $\mathbf{3 0}$ & 0,19 & 0,22 & 0,24 & 0,29 \\
\hline $\mathbf{3 5}$ & 0,18 & 0,20 & 0,23 & 0,27 \\
\hline $\mathbf{4 0}$ & 0,17 & 0,19 & 0,21 & 0,25 \\
\hline $\mathbf{4 5}$ & 0,16 & 0,18 & 0,20 & 0,24 \\
\hline $\mathbf{5 0}$ & 0,15 & 0,17 & 0,19 & 0,23 \\
\hline $\mathbf{5 0}$ & $\frac{1,07}{\sqrt{n}}$ & $\frac{1,22}{\sqrt{n}}$ & $\frac{1,36}{\sqrt{n}}$ & $\frac{1,63}{\sqrt{n}}$ \\
\hline
\end{tabular}

(Sumber: SNI 2415:2016)

Cari harga mutlak perbedaan maksimum antara distribusi empiris ( $\mathrm{P}$ empiris) dengan distribusi teoritis ( $\mathrm{P}$ teoritis)

$$
\Delta=\text { maksimum } \mid \text { Pteoritis - Pempiris } \mid
$$

Apabila nilai $\Delta \leq \Delta$ kritis sesuai harga kritis uji Kolmogorov-Smirnov seperti Tabel 1 maka distribusi teoritisnya dapat diterima dan bila terjadi sebaliknya maka distribusi teoritisnya ditolak. 


\section{Hujan rencana}

Hujan adalah sebuah proses kondensasi uap air di atmosfer menjadi butir air yang cukup berat untuk jatuh dan biasanya tiba di permukaan. Hujan biasanya terjadi karena pendinginan suhu udara atau penambahan uap air ke udara. Analisa distribusi curah hujan dari data hujan yang tersedia dapat dilakukan dengan beberapa metode antara lain Normal, log normal, log Pearson III dan Gumbel. Berikut ini adalah beberapa macam distribusi yang digunakan dalam penelitian ini untuk menganalisis probabilitas debit rencana, yaitu:

1. Distribusi Normal

Dalam analisis hidrologi distribusi normal sering digunakan untuk menganalisis frekuensi curah hujan, analisis statistik dari distribusi curah hujan tahunan, debit rata-rata tahunan. Sebaran normal atau kurva normal disebut pula sebaran Gauss. Rumus yang digunakan dalam perhitungan adalah:

$$
\mathrm{X}_{\mathrm{t}}=\overline{\mathrm{X}}+\mathrm{z} \cdot \mathrm{S}_{\mathrm{x}}
$$

2. Metode Distribusi Log Normal

Distribusi Log Normal, merupakan hasil transformasi dari distribusi normal, yaitu dengan mengubah varian $\mathrm{X}$ menjadi nilai logaritmik varian X. Rumus yang digunakan dalam perhitungan metode ini adalah sebagai berikut:

$$
\log X_{t}=\bar{X}+K_{t} \cdot S_{x}
$$

3. Distribusi Gumbel Tipe - I

Distribusi Gumbel Tipe - I digunakan untuk analisis data maksimum, misal untuk analisis frekuensi banjir.

$$
\mathrm{X}_{\mathrm{t}}=\overline{\mathrm{x}}+\frac{\left(\mathrm{Y}_{\mathrm{t}}-\mathrm{Y}_{\mathrm{n}}\right)}{\mathrm{S}_{\mathrm{n}}} \times \mathrm{S}_{\mathrm{x}}
$$

4. Distribusi Log Pearson Tipe - III

Distribusi Log Pearson Tipe III digunakan dalam analisis hidrologi, terutama dalam analisis data maksimum (banjir) dan minimum (debit minimum) dengan nilai ekstrim. Bentuk sebaran Log Pearson tipe III merupakan hasil transformasi dari sebaran Pearson tipe III dengan menggantikan varian menjadi nilai logaritmik. Langkah-langkah perhitungannya adalah sebagai berikut (Soemarto, 1995):

1. Mengubah data curah hujan sebanyak $n$ buah $\mathrm{X} 1, \mathrm{X} 2, \mathrm{X} 3, \ldots \mathrm{Xn}$ menjadi $\log (\mathrm{X} 1), \log (\mathrm{X} 2)$, $\log (\mathrm{X} 3), \ldots, \log (\mathrm{Xn})$.

2. Menghitung harga rata-ratanya dengan rumus :

$$
\log \overline{\mathrm{X}}=\frac{\sum_{\mathrm{i}=1}^{\mathrm{n}} \log \left(\mathrm{X}_{\mathrm{i}}\right)}{\mathrm{n}}
$$

3. Menghitung logaritma hujan rencana dengan periode ulang $\mathrm{T}$ tahun dengan rumus :

$$
\mathrm{S}=\frac{\sum_{\mathrm{i}=1}^{\mathrm{n}}\left\{\log \left(\mathrm{X}_{\mathrm{i}}\right)-\log (\overline{\mathrm{X}})\right\}^{2}}{\mathrm{n}-1}
$$

4. Menghitung koefisien skewness (Cs) dengan rumus :

$$
\mathrm{C}_{\mathrm{s}}=\frac{\sum_{\mathrm{i}=1}^{\mathrm{n}}\left\{\log \left(\mathrm{X}_{\mathrm{i}}\right)-\log (\overline{\mathrm{X}})\right\}^{2}}{(\mathrm{n}-1)(\mathrm{n}-2) \mathrm{S}^{3}}
$$

5. Menghitung logaritma hujan rencana dengan periode ulang $\mathrm{T}$ tahun dengan rumus :

$$
\begin{aligned}
\log \mathrm{Y} & =\log \overline{\mathrm{X}}+\mathrm{k} \cdot \mathrm{S} \\
\mathrm{X}_{\mathrm{t}} & =10^{(\log \mathrm{Y})}
\end{aligned}
$$


Berikut ini adalah syarat untuk penentuan jenis-jenis distribusi, yang terdapat pada tabel 2.

Tabel 2. Penentuan jenis-jenis distribusi

\begin{tabular}{|c|c|c|}
\hline No & Jenis Distribusi & Syarat \\
\hline 1 & Distribusi Normal & $\mathrm{CS}=0$ \\
\hline 2 & Distribusi Log- Normal & $\mathrm{CS}=3 \mathrm{CV}$ \\
\hline 3 & Distribusi Gumbel & $\begin{array}{l}\mathrm{Cs} \sim 1.14 \\
\mathrm{Ck} \sim 5,4002\end{array}$ \\
\hline 4 & Distribusi Log-Pearson Tipe III & Selain dari nilai di atas. \\
\hline
\end{tabular}

(Sumber: Triatmodjo, 2015)

Distribusi Log Pearson III, mempunyai koefisien kemencengan (Coefisien of skewnnes) atau CS. Setelah pemilihan jenis sebaran dilakukan maka prosedur selanjutnya yaitu mencari curah hujan rencana periode ulang 2, 5, 10, 25, 50 dan 100 tahun.

\section{Intensitas hujan}

Intensitas Hujan besaran ketinggian hujan yang ditetapkan sebagai harga perencanaan yang memperhatikan periode ulang yang dihitung dengan metode yang lazim dalam analisis hidrologi (SNI 8456:2017). Waktu konsentrasi (tc) adalah waktu yang diperlukan oleh titik air hujan yang jatuh terjauh pada permukaan tanah dalam Daerah Tangkapan Air ke saluran terdekat (to) dan ditambah waktu untuk mengalir sampai di suatu titik di saluran drainase yang ditinjau (td) (Kementerian Pekerjaan Umum Direktorat Jendreal Cipta Karya, 2013). Intensitas Hujan besaran ketinggian hujan yang ditetapkan sebagai harga perencanaan yang memperhatikan periode ulang yang dihitung dengan metode yang lazim dalam analisis hidrologi (SNI 8456:2017). Menurut Dr. Mononobe jika data curah hujan yang ada hanya curah hujan harian. Rumus yang digunakan:

Rumus yang digunakan:

$$
I=\frac{R_{24}}{24}\left(\frac{24}{t_{c}}\right)^{\frac{2}{3}}
$$

\section{Debit rancangan dengan metode rasional}

Debit rencana drainase perkotaan dihitung dengan metode rasional yang telah dimodifikasi dan atau typical hydrogram for urban areas. Koefisien limpasan (run off) ditentukan berdasarkan tata guna lahan daerah tangkapan (Peraturan Menteri Pekerjaan Umum Republik Indonesia Nomor 12/PRT/M/2014 Tentang Penyelenggaraan Sistem Drainase Perkotaan). Berikut adalah rumus Modified Rational Method atau rational method yang dimodifikasi persamaannya sebagai berikut

$$
\mathrm{Q}=0,00278 \text {.Cs. C.I. A }
$$

Metode rasional praktis Metode ini dapat menggambarkan hubungan antara debit limpasan dengan besar curah hujan secara praktis berlaku untuk luas DAS hingga 5.000 hektar. Dua komponen utama ialah waktu konsentrasi (tc) dan intensitas curah hujan (itc).Persamaan menurut (SNI 2415:2016) yang digunakan:

$$
\mathrm{Qp}=0,00278 \text { C.I.A }
$$

\section{Koefisien Pengaliran/ Koefisien Limpasan (C)}

Air hujan yang turun dari atmosfer jika kita ditangkap oleh vegetasi atau oleh permukaan-permukaan buatan seperti atap bangunan atau lapisan kedap air lainnya, maka akan jatuh ke permukaan bumi dan sebagian akan menguap, berinfiltrasi atau tersimpan dalam cekungan-cekungan. Bila kehilangan seperti cara-cara tersebut telah terpenuhi, maka sisa air hujan akan langsung mengalir diatas permukaan tanah menuju alur aliran terdekat. Dalam perencanaan drainase, bagian air hujan yang menjadi pengendalian air banjir tidak hanya aliran permukaan (surface run off), sedangkan untuk pengendalian banjir tidak hanya aliran permukaan, tetapi limpasan (run off). Limpasan merupakan gabungan antara aliran permukaan, aliran-aliran tertunda pada cekungan-cekungan dan aliran bawah permukaan (sub surface flow). (Suripin, 2004). Berikut adalah tabel nilai koefisien limpasan yang terdapat pada tabel 3 berikut ini. 
Tabel 3. Nilai koefisien limpasan

\begin{tabular}{|c|c|c|c|}
\hline Jenis Daerah & $\begin{array}{l}\text { Koefisien } \\
\text { Aliran }\end{array}$ & Kondisi Permukaan & $\begin{array}{c}\text { Koefisien } \\
\text { Aliran }\end{array}$ \\
\hline Daerah Perdagangan & & Jalan Aspal & \\
\hline Kota & $0,70-0,95$ & Aspal dan beton & $0,75-0,95$ \\
\hline Sekitar kita & $0,50-0,70$ & Batu bata dan batako & $0,70-0,85$ \\
\hline Daerah Pemukiman & & Atap Rumah & $0,70-0,95$ \\
\hline Satu rumah & $0,30-0,50$ & $\begin{array}{l}\text { Halaman berumput, tanah } \\
\text { pasir }\end{array}$ & \\
\hline Banyak Rumah,terpisah & $0,40-0,60$ & Datar, $2 \%$ & $0,05-0,10$ \\
\hline Banyak Rumah, rapat & $0,60-0,75$ & Rata-rata,2-7 \% & $0,10-0,15$ \\
\hline Pemukiman, pinggiran Kota & $0,25-0,40$ & Curam, $7 \%$ atau lebih & $0,15-0,20$ \\
\hline Apartemen & $0,50-0,70$ & & \\
\hline Daerah Industri & & $\begin{array}{l}\text { Halaman berumput,tanah } \\
\text { pasir padat }\end{array}$ & \\
\hline Ringan & $0,50-0,80$ & Datar, $2 \%$ & $0,13-0,17$ \\
\hline Padat & $0,60-0,90$ & Rata-Rata, 2-7\% & $0,18-0,22$ \\
\hline Lapangan, kuburan dan sejenisnya & $0,10-0,25$ & Curam, $7 \%$ atau lebih & $0,25-0,35$ \\
\hline $\begin{array}{l}\text { Halaman, jalan kereta api dan } \\
\text { sejenisnya }\end{array}$ & $0,20-0,35$ & & \\
\hline Lahan tidak terpelihara & $0,10-0,30$ & & \\
\hline
\end{tabular}

(Sumber: SNI 2415:2016)

\section{METODE PENELITIAN}

Metodologi penelitian akan dilakukan dengan tahapan sebagai berikut:

1. Menganalisa curah hujan yaitu dengan mengambil data curah hujan maksimum tiap tahun.

2. Menganalisa frekuensi curah hujan dengan menggunakan empat jenis distribusi yang digunakan dalam bidang hidrologi yaitu Distribusi Normal, Log Normal, Gumbel tipe I dan Log Pearson tipe III yang nantinya disesusaikan dengan pengujian parameter statistik analisis frekuensi.

3. Melakukan perhitungan intensitas hujan dengan metode mononobe. Ini dikarenakan data jangka pendek tidak tersedia, yang ada hanya data hujan harian maksimum.

4. Menentukan daerah tangkapan air dari masing-masing saluran.

5. Menghitung debit rencana, yaitu penjumlahan antara debit air hujan dengan debit air kotor.

6. Menghitung debit saluran eksisting drainase.

7. Menganalisa apakah kapasitas saluran drainase tersebut cukup menampung debit rencana atau tidak, jika tidak maka perlu direncanakan saluran drainase yang baru.

8. Memberikan kesimpulan terhadap analisa drainase eksisting di lapangan terhadap debit banjir rencana.

Sesuai dengan poin-poin tersebut, berikut adalah diagram alir untuk penelitian yang dilakukan yang terdapat pada gambar 1. 


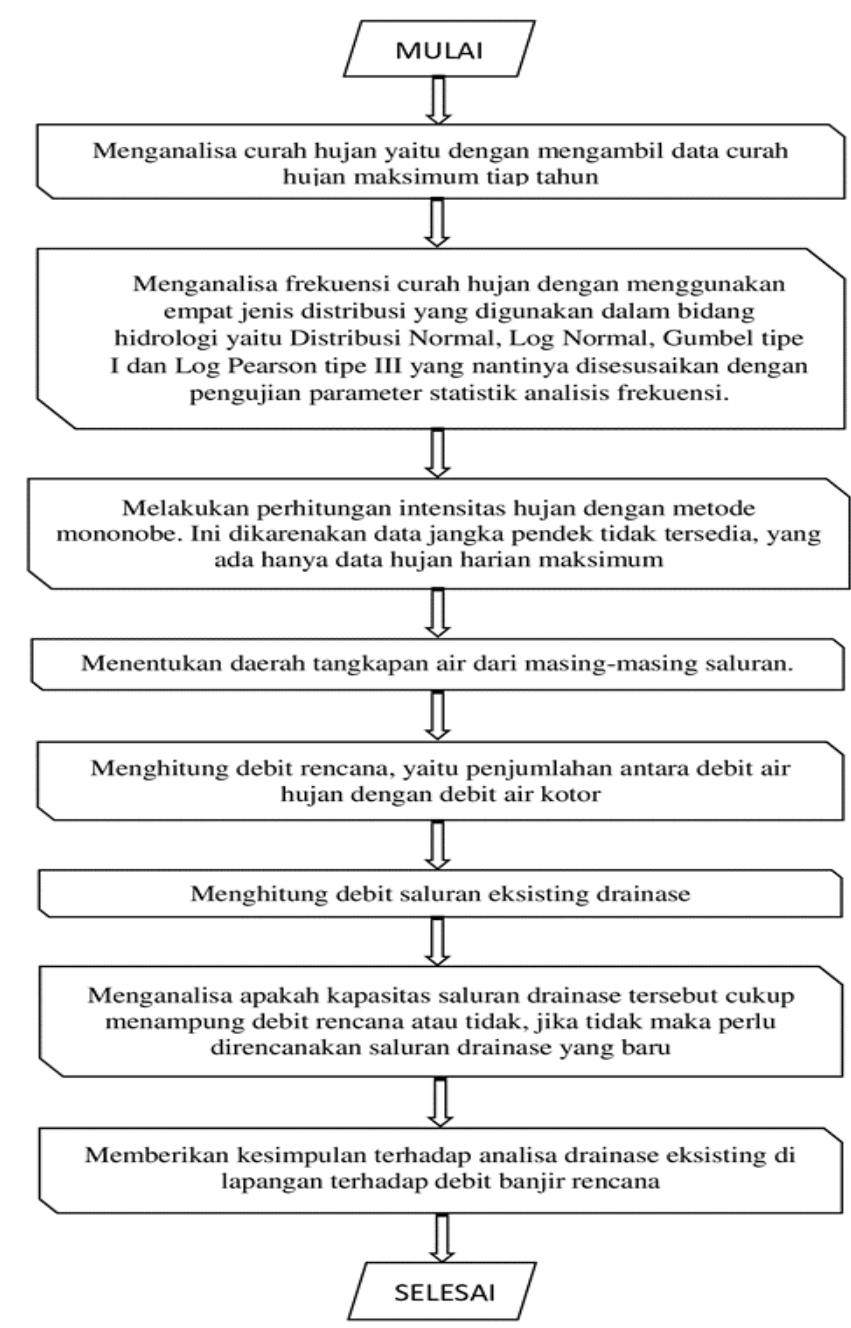

Gambar 1. Diagram alir

\section{HASIL DAN PEMBAHASAN}

\section{Kesimpulan syarat penentuan jenis-jenis distribusi}

Pada subbab ini merupakan hasil rekapitulasi dari gabungan uji Chi-Kuadrat dan uji Smirnov Kolmogorov, beserta kesimpulan terhadap distribusi yang dipilih dan digunakan untuk menghitung curah hujan rencana. Seperti yang terdapat pada tabel 4 berikut ini.

Tabel 4. Rekapitulasi dari uji chi-kuadrat dan uji smirnov-kolmogorov

\begin{tabular}{|c|c|c|c|c|c|c|c|}
\hline \multirow{2}{*}{ No. } & \multirow{2}{*}{ Distribusi } & \multicolumn{2}{|c|}{ Chi Kuadrat } & \multirow{2}{*}{ Kesimpulan } & \multicolumn{2}{|c|}{$\begin{array}{c}\text { Kolmogorov } \\
\text { Smirnov }\end{array}$} & \multirow{2}{*}{ Kesimpulan } \\
\hline & & $\begin{array}{c}\text { X2 } \\
\text { Teori }\end{array}$ & $\mathrm{X} 2 \mathrm{Cr}$ & & $\begin{array}{c}\Delta \mathbf{P} \\
\text { Kritis }\end{array}$ & $\Delta \mathbf{P}$ & \\
\hline 1 & Normal & 5,991 & 15,5 & $\begin{array}{c}\text { Tidak Dapat } \\
\text { Diterima }\end{array}$ & 0,34 & 0,1221 & $\begin{array}{c}\text { Dapat } \\
\text { Diterima }\end{array}$ \\
\hline 2 & Log Normal & 5,991 & 7,5 & $\begin{array}{c}\text { Tidak Dapat } \\
\text { Diterima }\end{array}$ & 0,34 & 0,1087 & $\begin{array}{c}\text { Dapat } \\
\text { Diterima }\end{array}$ \\
\hline 3 & Gumbel & 5,991 & 10,5 & $\begin{array}{c}\text { Tidak Dapat } \\
\text { Diterima }\end{array}$ & 0,34 & 0,0788 & $\begin{array}{c}\text { Dapat } \\
\text { Diterima }\end{array}$ \\
\hline 4 & Log Pearson Tipe 3 & 5,991 & 3,5 & $\begin{array}{c}\text { Dapat } \\
\text { Diterima }\end{array}$ & 0,34 & 0,0631 & $\begin{array}{c}\text { Dapat } \\
\text { Diterima }\end{array}$ \\
\hline
\end{tabular}




\section{Analisis curah hujan rencana Metode Distribusi Log-Pearson Tipe 3}

Pada subbab ini dibahas tentang perhitungan curah hujan rencana dengan metode Distribusi Log Pearson Tipe 3. Pada analisis curah hujan ini menggunakan periode ulang 5 tahun. Hasil analisis perhitungan curah hujan dengan metode distribusi Log Pearson Tipe 3 terdapat pada tabel 5 berikut ini.

Tabel 5. Hasil perhitungan curah hujan dengan metode distribusi Log Pearson Tipe 3

\begin{tabular}{ccccccc}
\hline \multicolumn{6}{c}{ METODE DISTRIBUSI LOG PEARSON TIPE 3 } \\
\hline \multirow{2}{*}{ No } & $\begin{array}{c}\text { T } \\
\text { Tahun }\end{array}$ & $\log \overline{\boldsymbol{X} \boldsymbol{\imath}}$ & $\mathbf{S x}$ & $\mathbf{K}_{\mathrm{T}}$ Log Pearson 3 & $\log \mathbf{X}_{\mathbf{T}}$ & $\mathbf{X}_{\mathbf{T}}$ Log Pearson 3 \\
\hline 1 & 2 & 2,02 & 0,1390 & $-0,18$ & 1,99 & $99,51 \mathrm{~mm}$ \\
$\mathbf{2}$ & $\mathbf{5}$ & $\mathbf{2 , 0 2}$ & $\mathbf{0 , 1 3 9 0}$ & $\mathbf{0 , 7 5 8}$ & $\mathbf{2 , 1 3}$ & $\mathbf{1 3 4 , 3 6 ~ \mathbf { m m }}$ \\
3 & 10 & 2,02 & 0,1390 & 1,341 & 2,21 & $161,93 \mathrm{~mm}$ \\
4 & 25 & 2,02 & 0,1390 & 2,066 & 2,31 & $204,23 \mathrm{~mm}$ \\
5 & 50 & 2,02 & 0,1390 & 2,585 & 2,38 & $241,14 \mathrm{~mm}$ \\
6 & 100 & 2,02 & 0,1390 & 3,087 & 2,45 & $283,18 \mathrm{~mm}$ \\
\hline
\end{tabular}

\section{Analisis intensitas hujan dengan metode Mononobe}

Untuk Intensitas hujan digunakan metode mononobe sesuai dengan (SNI 8456:2017). Pada analisis intensitas hujan berikut ini menggunakan periode ulang 5 tahun dan untuk hasil analisisnya terdapat pada tabel 6 berikut ini.

Tabel 6. Hasil perhitungan intensitas curah hujan cara mononobe

\begin{tabular}{|c|c|c|c|c|c|c|c|c|}
\hline \multirow{4}{*}{ No. } & \multirow{4}{*}{ Saluran } & \multirow{4}{*}{$\begin{array}{l}\text { Durasi } \\
\text { (Jam) }\end{array}$} & \multicolumn{6}{|c|}{ Curah Hujan Harian Maksimum 24 Jam (R24) (mm/24 jam) } \\
\hline & & & 2 Tahun & 5 Tahun & 10 Tahun & 25 Tahun & 50 Tahun & 100 Tahun \\
\hline & & & 99,5062 & 134,3570 & 161,9253 & 204,2263 & 241,1395 & 283,1793 \\
\hline & & & \multicolumn{6}{|c|}{ Intensitas Hujan Rencana dengan rumus Mononobe (mm/jam) } \\
\hline 1 & $\mathrm{P} 1-\mathrm{P} 2$ & 141,8155 & 1,2685 & 1,7128 & 2,0642 & 2,6035 & 3,0741 & 3,6100 \\
\hline 2 & P2-P5 & 162,2153 & 1,1598 & 1,5660 & 1,8873 & 2,3804 & 2,8106 & 3,3006 \\
\hline 3 & P3-P2 & 142,1875 & 1,2663 & 1,7098 & 2,0606 & 2,5990 & 3,0687 & 3,6037 \\
\hline 4 & P5-P6 & 96,5217 & 1,6394 & 2,2136 & 2,6678 & 3,3648 & 3,9730 & 4,6656 \\
\hline 5 & P6-P12 & 76,8049 & 1,9092 & 2,5779 & 3,1068 & 3,9185 & 4,6267 & 5,4333 \\
\hline 6 & P10-P11 & 90,7225 & 1,7086 & 2,3070 & 2,7804 & 3,5067 & 4,1405 & 4,8624 \\
\hline 7 & P11-P5 & 162,2153 & 1,1598 & 1,5660 & 1,8873 & 2,3804 & 2,8106 & 3,3006 \\
\hline 8 & P11-P12 & 76,8050 & 1,9092 & 2,5779 & 3,1068 & 3,9185 & 4,6267 & 5,4333 \\
\hline
\end{tabular}

\section{Analisis debit rancangan dengan Metode Rasional}

Untuk Debit Rancangan digunakan metode rasional praktis karena luas pengaliran tidak lebih dari 5000 ha. Berikut ini adalah hasil perhitungan debit rancangan tersebut yang terdapat pada tabel 7 berikut ini, dengan periode ulang rencana 5 tahun.

Tabel 7. Debit rancangan dengan metode rasional

\begin{tabular}{|c|c|c|c|c|c|c|c|c|c|}
\hline \multirow{4}{*}{ No } & \multirow{4}{*}{ Saluran } & \multirow{4}{*}{$\begin{array}{c}\text { Luas } \\
\text { Tangkapan } \\
\text { (Ha) }\end{array}$} & \multirow{4}{*}{$\begin{array}{c}\text { Durasi } \\
\text { (Jam) }\end{array}$} & \multicolumn{6}{|c|}{ Curah Hujan Harian Maksimum 24 Jam (R24) (mm/24 jam) } \\
\hline & & & & 2 Tahun & 5 Tahun & 10 Tahun & 25 Tahun & 50 Tahun & $\begin{array}{c}100 \\
\text { Tahun }\end{array}$ \\
\hline & & & & 99,5062 & 134,3570 & 161,9253 & 204,2263 & 241,1395 & 283,1793 \\
\hline & & & & \multicolumn{6}{|c|}{ Debit Rancangan Dengan Metode Rasional $\left(\mathrm{m}^{3} / \mathrm{s}\right)$} \\
\hline 1 & P1-P2 & 26,75 & 141,8155 & 0,0660 & 0,0892 & 0,1075 & 0,1355 & 0,1600 & 0,1879 \\
\hline 2 & P2-P5 & 80,25 & 90,7225 & 0,2668 & 0,3603 & 0,4342 & 0,5476 & 0,6466 & 0,7593 \\
\hline 3 & P3-P2 & 90,85 & 103,5197 & 0,2766 & 0,3735 & 0,4502 & 0,5678 & 0,6704 & 0,7872 \\
\hline 4 & P5-P6 & 172,65 & 76,8049 & 0,6415 & 0,8661 & 1,0438 & 1,3165 & 1,5545 & 1,8255 \\
\hline 5 & P6-P12 & 53,5 & 162,2153 & 0,1207 & 0,1630 & 0,1965 & 0,2478 & 0,2926 & 0,3436 \\
\hline 6 & P10-P11 & 26,75 & 142,1875 & 0,0659 & 0,0890 & 0,1073 & 0,1353 & 0,1597 & 0,1876 \\
\hline 7 & P11-P5 & 100,75 & 96,5217 & 0,3214 & 0,4340 & 0,5231 & 0,6597 & 0,7789 & 0,9147 \\
\hline 8 & P11-P12 & 136,75 & 76,8049 & 0,5081 & 0,6860 & 0,8268 & 1,0428 & 1,2312 & 1,4459 \\
\hline
\end{tabular}




\section{Analisis saluran drainase rencana}

Setelah dianalisis ternyata saluran eksisting tidak dapat memenuhi maka dibuat drainase rencana yang bisa menampung debit dari analisis hidrologi tersebut, dengan ukuran yang terdapat pada tabel 8 sebagai berikut ini.

Tabel 8. Saluran drainase rencana

\begin{tabular}{|c|c|c|c|c|c|c|c|c|c|}
\hline \multicolumn{10}{|c|}{ DESAIN DRAINASE RENCANA } \\
\hline \multirow{3}{*}{ No. } & \multirow{3}{*}{ Saluran } & \multirow{3}{*}{$\begin{array}{c}\text { Q } \\
\text { Hidrologi } \\
(\mathrm{m} 3 / \mathbf{s})\end{array}$} & \multirow{3}{*}{$\begin{array}{c}\mathbf{Q} \\
\text { Saluran } \\
\text { Rencana } \\
(\mathbf{m 3} / \mathbf{s})\end{array}$} & \multirow{3}{*}{$\begin{array}{l}\text { Kemiringan } \\
\text { Dasar } \\
\text { Saluran (m) }\end{array}$} & \multirow{3}{*}{$\begin{array}{c}\mathrm{V} \\
(\mathrm{m} 2 / \mathrm{s})\end{array}$} & \multicolumn{2}{|c|}{ Lebar (b) } & \multirow{2}{*}{$\begin{array}{l}\text { Tinggi } \\
\text { (h) }\end{array}$} & \multirow{2}{*}{$\begin{array}{c}\text { Tinggi } \\
\text { Jagaan } \\
\text { (fb) }\end{array}$} \\
\hline & & & & & & Atas & Bawah & & \\
\hline & & & & & & $\mathbf{m}$ & m & $\mathbf{m}$ & $\mathbf{m}$ \\
\hline 1 & P1-P2 & 0,0892 & 0,0958 & 0,001 & 0,3831 & 0,5 & 0,5 & 0,5 & 0,125 \\
\hline 2 & P2-P5 & 0,3603 & 0,4592 & 0,001 & 0,5669 & 0,9 & 0,9 & 0,9 & 0,225 \\
\hline 3 & P3-P2 & 0,3735 & 0,4592 & 0,001 & 0,5669 & 0,9 & 0,9 & 0,9 & 0,225 \\
\hline 4 & P5-P6 & 0,8661 & 0,9888 & 0,001 & 0,6867 & 1,2 & 1,2 & 1,2 & 0,3 \\
\hline 5 & P6-P12 & 0,1630 & 0,0958 & 0,001 & 0,0958 & 0,5 & 0,5 & 0,5 & 0,125 \\
\hline 6 & P10-P11 & 0,0890 & 0,0958 & 0,001 & 0,3831 & 0,5 & 0,5 & 0,5 & 0,125 \\
\hline 7 & P11-P5 & 0,4340 & 0,4592 & 0,001 & 0,3831 & 0,9 & 0,9 & 0,9 & 0,225 \\
\hline 8 & P11-P12 & 0,6860 & 0,7841 & 0,001 & 0,6480 & 1,1 & 1,1 & 1,1 & 0,275 \\
\hline
\end{tabular}

\section{Perbandingan debit saluran eksisting dengan debit saluran rencana}

Berikut adalah hasil perbandingan antara debit saluran eksisting dari Bappeda Kabupaten Tangerang dengan hasil debit saluran rencana penulis yang terdapat pada tabel 9 berikut ini.

Tabel 9. Perbandingan Q saluran

\begin{tabular}{cccc}
\hline & \multicolumn{2}{c}{ PERBANDINGAN Q SALURAN } & \\
\hline No. & Saluran & $\begin{array}{c}\text { Q Saluran } \\
\text { Rencana } \\
\text { Hasil Analisis }\end{array}$ \\
\cline { 3 - 4 } & & $\mathbf{m}^{\mathbf{3} / \mathbf{s}}$ & $\mathbf{\mathbf { m } ^ { \mathbf { 3 } } / \mathbf { s }}$ \\
\hline 1 & $\mathrm{P} 1-\mathrm{P} 2$ & 0,0897 & 0,0958 \\
\hline 2 & $\mathrm{P} 2-\mathrm{P} 5$ & 0,2760 & 0,4592 \\
\hline 3 & $\mathrm{P} 3-\mathrm{P} 2$ & 0,0895 & 0,4592 \\
\hline 4 & $\mathrm{P} 5-\mathrm{P} 6$ & 0,2760 & 0,9888 \\
\hline 5 & P6-P12 & 0,3935 & 0,2349 \\
\hline 6 & P10-P11 & 0,0406 & 0,0958 \\
\hline 7 & P11-P5 & 0,2760 & 0,4592 \\
\hline 8 & P11-P12 & 0,7293 & 0,7841 \\
\hline
\end{tabular}

Analisis terhadap perbedaan Q saluran ini dapat dikarenakan pada perbedaan Q rencana hidrologi, dan pada desain dimensi saluran dari masing-masing perencana.

\section{Perbandingan dimensi saluran eksisting dengan dimensi rencana}

Berikut ini adalah hasil perbandingan antara dimensi saluran eksisting dari Bappeda Kabupaten Tangerang dengan dimensi rencana hasil analisis penulis yang terdapat pada tabel 10 berikut ini. 
Tabel 10. Perbandingan dimensi saluran drainase eksisting dengan saluran rencana

\begin{tabular}{|c|c|c|c|c|c|c|c|c|c|}
\hline \multicolumn{10}{|c|}{ PERBANDINGAN DIMENSI SALURAN EKSISTING DENGAN SALURAN RENCANA } \\
\hline \multirow{4}{*}{ No. } & \multirow{4}{*}{ Saluran } & \multicolumn{4}{|c|}{ Dimensi Eksisting } & \multicolumn{4}{|c|}{ Dimensi Saluran Rencana } \\
\hline & & \multicolumn{2}{|c|}{ Lebar (b) } & \multirow{2}{*}{$\begin{array}{l}\text { Tinggi } \\
\text { (h) }\end{array}$} & \multirow{2}{*}{$\begin{array}{c}\text { Tinggi } \\
\text { Jagaan } \\
\text { (fb) }\end{array}$} & \multicolumn{2}{|c|}{ Lebar (b) } & \multirow{2}{*}{$\begin{array}{l}\text { Tinggi } \\
\text { (h) }\end{array}$} & \multirow[b]{2}{*}{ Tinggi Jagaan (fb) } \\
\hline & & Atas & Bawah & & & Atas & Bawah & & \\
\hline & & $\mathbf{m}$ & $\mathbf{m}$ & $\mathbf{m}$ & $\mathbf{m}$ & $\mathbf{m}$ & $\mathbf{m}$ & $\mathbf{m}$ & $\mathbf{m}$ \\
\hline 1 & P1 & 1 & 1 & 0,5 & 0,1 & 0,5 & 0,5 & 0,5 & 0,125 \\
\hline 2 & $\mathrm{P} 2$ & 1 & 1 & 0,5 & 0,1 & 0,9 & 0,9 & 0,9 & 0,225 \\
\hline 3 & P3 & 1 & 1 & 0,5 & 0,1 & 0,9 & 0,9 & 0,9 & 0,225 \\
\hline 4 & P5 & 1 & 1 & 1 & 0,2 & 1,2 & 1,2 & 1,2 & 0,3 \\
\hline 5 & P6 & 0,5 & 0,5 & 0,5 & 0,1 & 0,5 & 0,5 & 0,5 & 0,125 \\
\hline 6 & P10 & 0,5 & 0,5 & 0,5 & 0,1 & 0,5 & 0,5 & 0,5 & 0,125 \\
\hline 7 & P11 & 0,5 & 0,5 & 0,5 & 0,1 & 0,9 & 0,9 & 0,9 & 0,225 \\
\hline 8 & P12 & 0,5 & 0,5 & 0,5 & 0,1 & 1,1 & 1,1 & 1,1 & 0,275 \\
\hline
\end{tabular}

Analisis terhadap perbedaan dimensi saluran eksisting dengan saluran rencana karena saluran eksisting sudah tidak mampu lagi menampung debit rencana baru, sehingga perlu diperbarui dimensinya, dari data maupun tinjauan lapangan drainase eksisting mengalami genangan air setiap kali hujan lebat, jadi dengan dimensi baru dapat mencegah masalah genangan air tersebut.

\section{KESIMPULAN DAN SARAN}

\section{Kesimpulan}

Berdasarkan hasil analisis dari penelitian yang telah dilakukan dapat disimpulkan hal-hal berikut ini.

1. Setelah dilakukan penelitian ternyata penyebab dari genangan air yang terjadi pada daerah Pasar KemisCikupa adalah saluran drainase yang tidak mampu lagi menampung debit air hujan oleh karena itu kapasitas salurannya sebaiknya diperbaiki.

2. Berdasarakan hasil perhitungan curah hujan pada daerah Pasar Kemis-Cikupa pada kurun waktu tahun 20042018 memiliki rata-rata hujan sebesar 53,7586 mm. Dalam penelitian ini Saluran yang dianalisis adalah saluran dengan nama P1-P2, P2-P5, P3-P2, P5-P6, P6-P12, P10-P11, P11-P5 ,dan P11-P12 karena berdasarkan data yang didapat didaerah sekitar saluran itu yang terjadi genangan. Untuk perhitungan curah hujan diuji dengan Uji Chi-Kuadrat dan Uji Smirnov-Kolomogorov dan menghasilkan distribusi yang tepat untuk curah hujan rencana adalah distribusi Log Pearson Tipe 3, yaitu sebesar 134,3570 mm dengan periode ulang 5 tahun, yang sesuai dengan periode ulang rencana dari Bappeda Kabupaten Tangerang.

3. Untuk perhitungan intensitas curah hujan memakai cara monobe yang sesuai dengan (SNI 8456:2017), yang hasilnya mengacu pada tabel 6. Dalam perhitungan debit rencana dengan cara metode rasional yang sesuai dengan (SNI 8456:2017) yang hasilnya mengacu pada tabel 7.

4. Berdasarkan tujuan awal penelitian yaitu meneliti pengaruh debit rencana terhadap dimensi saluran saluran eksisting yang dapat disimpulkan bahwa saluran drainase eksisting sudah tidak mampu lagi menampung debit aliran air dan harus dibuat ulang sesuai dengan saluran rencana. Hal ini dapat mengacu pada tabel 9 dimana saluran eksisting sudah tidak dapat menampung lagi sehingga harus didesain ulang sesuai dengan tabel 10.

\section{Saran}

Berdasarkan hasil analisis ternyata saluran drainase eksisting tidak mampu lagi menampung debit air rencana, sehingga direkomendasikan saran berikut ini agar saluran dapat berfungsi normal kembali:

1. Dari hasil analisis saluran drainase, disarankan untuk ukuran saluran yang baru pada setiap saluran sesuai dengan mengacu pada tabel 8.

2. Berdasarkan pengalaman dari peninjauan lapangan disarankan agar sering dilakukan normalisasi saluran drainasenya, karena banyak sekali sampah yang membuat air jadi lambat dan menyebabkan genangan air.

3. Karena ini merupakan daerah padat penduduk diharapkan agar pemerintah juga melakukan sosialisasi untuk menjaga dan merawat drainase, karena bila sudah terjadi genangan air kepentingan umum juga tidak terhambat salah satunya kemacetan, dan yang paling besar adalah banjir yang merugikan masyarakat.

4. Dalam mendesain saluran drainase agar disesuaikan dengan analisis debit hidrologi rencana hal ini dapat mengacu pada tabel 9, dimana perancangan awal pada debit hidrologi rencana untuk drainase eksisting, tidak disesuaikan dimensinya, hal ini dapat mengacu pada tabel 10, dimana kurang idealnya desain dimensi saluran eksisting, sehingga debit rancangan jauh lebih besar dibanding dengan debit maksimum saluran. Hal ini kurang tepat yang seharusnya debit rancangan harus lebih kecil dari debit maksimum saluran. 


\section{DAFTAR PUSTAKA}

Asdak, Chay. "Hidrologi Dan Pengelolaan Daerah Aliran Sungai." Gajah Mada University Press (2002).

Badan Perencanaan Pembangunan Daerah Kabupaten Tangerang. "Pokja AMPL Kabupaten Tangerang." Tangerang, Badan Perencanaan Pembangunan Daerah Kabupaten. Buku Putih Sanitasi Kabupaten. Kabupaten Tangerang: Badan Perencanaan Pembangunan Daerah Kabupaten Tangerang, 2012. 9.

Badan Standardisasi Nasional. “SNI 2415:2016.” Tata cara perhitungan debit banjir rencana (2016).

Badan Standardisasi Nasional. “SNI 8456:2017.” Sumur Dan Parit Resapan Hujan (2017).

Bappeda Kabupaten Tangerang. “Laporan Final.” Fasilitasi Penyusunan Masterplan dan DED Drainase Kabupaten Tangerang (2014).

Dinas Pemadam Kebakaran dan Bencana Kabupaten Tangerang. “Analisa Prioritas Genangan.” Laporan Final Fasilitasi Masterplan dan DED Kabupaten Tangerang (2014): IV-3.

Dinas RT/RW Kabupaten Tangerang. "Buku Putih Sanitasi Kabupaten Tangerang." Pokja AMPL Kabupaten Tangerang (2012): 20.

Kementerian Pekerjaan Umum Direktorat Jenderal Cipta Karya. "Buku Panduan Drainase Berbasis Masyarakat." Direktorat Pengembangan Penyehatan Lingkungan Permukiman (2013).

Kottegoda, Nathabantu T. Statistics, Probability And Reliability Methods for Civil and Environmental Engineers. McGraw-Hill College, 1996.

Moduto. Desain Drainase Perkotaan Volume 1. Bandung: Departemen Teknik Lingkungan ITB, 1998.

Peraturan Menteri Pekerjaan Umum Republik Indonesia. "Nomor 12/PRT/M/2014." Tentang Penyelenggaraan Sistem Drainase Perkotaan (2014).

Peraturan Pemerintah Nomor 42 Tahun 2008. "Peraturan Pemerintah Nomor 42 Tahun 2008 Tentang Pengelolaan Sumber Daya Air." 2008.

Puji, Dwininda Arum. "Kapasitas Infiltrasi Pada Berbagi Kerapatan Tajuk Di Daerah Tangkapan Air (DTA)." Repositori Universitas Gadjah Mada (2017).

Soemarto, C.D. Hidrologi Teknik Edisi Ke-2. Jakrata: Erlangga, 1995.

Supriadi. “Analisis Genangan Air Pada Prasarana Jalan dan Kaitannya Dengan Pengembangan Wilayah Di Kota Medan.” University of Sumatera Utara Institutional Repository (2008): 10.

Suripin. Sistem Drainase Yang Berkelanjutan. Yogyakarta: Andy, 2004.

Tangerang, Dinas RT/RW Kabupaten. "Buku Putih Sanitasi Kabupaten Tangerang.” Pokja AMPL Kabupaten Tangerang (2012): 20.

Triatmodjo, Bambang. Hidrologi Terapan, Beta Offset. Yogyakarta, 2008. 